\title{
Sudden Sensorineural Hearing Loss Post Coronavirus Disease: A Systematic Review of Case Reports
}

\author{
Abishek Umashankar ${ }^{1} \cdot$ Praveen Prakash $^{1} \cdot$ Prashanth Prabhu $^{1}$ (D)
}

Received: 24 April 2021 / Accepted: 4 July 2021 / Published online: 10 July 2021

(C) Association of Otolaryngologists of India 2021

\begin{abstract}
The coronavirus disease of 2019 is a global pandemic disease severely affecting the upper respiratory tract that can be fatal in some instances. The virus most commonly affects the respiratory system. However, in certain cases it affects the other systems, including cardiovascular, renal, gastrointestinal, neurological, and auditory. Concerning the hearing and balance system, the microcirculation supply to the inner ear is hampered thus causing audiovestibular symptoms. Several case studies have reported sudden sensorineural hearing loss postcoronavirus disease and its detrimental impact on overall hearing. As both sudden sensorineural hearing loss and coronavirus disease deals with an emergency situation, there is a need to document case studies on how these individuals have been assessed and treated. The article has systematically reviewed these case reports involving a search strategy in databases like PubMed, PubMed Central, science direct, J-GATE, Google Scholar, and a manual Google Search.
\end{abstract}

Keywords SARS-COV-2 - Systematic review · Sudden sensorineural hearing loss $\cdot$ Neuritis . Intratympanic steroids

Prashanth Prabhu

prashanth.audio@gmail.com

1 All India Institute of Speech and Hearing, Mysore, Karnataka 570006, India

\section{Introduction}

The coronavirus disease of 2019, also known as COVID-19 or SARS-COV-2 is one of the deadliest pandemic diseases currently impacting mankind. An individual affected with the disease presents with various symptoms that initially begin with fever, cough, sore throat, breathlessness, fatigue, and malaise. It may progress to pneumonia, Acute Respiratory Distress Syndrome (ARDS) and multi-organ dysfunction. The final stage can be fatal, and recovery may seem strenuous $[1,2]$. Though many vaccines were introduced, the disease has hit second and third waves in many countries, elevating the number of infected individuals getting infected [3]. Apart from those individuals who present with COVID 19 symptoms of upper respiratory tract infection, there have been notable cases of sporadic symptoms. Some of them include; sudden cardiac death, acute kidney injury, liver failure, stroke, and gastrointestinal disease [4-8]. An infrequent symptom of COVID19 disease documented in some literature over the past one year post-COVID outbreak is hearing loss [9]. It has been attributed that the virus creates a negative impact on an individual's hearing sensitivity [10]. Not only the hearing sensitivity of an individual, the Coronavirus infection also results in other audio vestibular symptoms such as tinnitus, and vertigo. [11]. Works of literature have discussed the mechanism behind COVID 19 and hearing loss. It is believed that labyrinthitis or neuritis, which causes symptoms like hearing loss, vertigo and tinnitus, occur due to upper respiratory tract infection resulting from Coronavirus infection [12]. Another justification is that cross-reaction may result in inner ear antigens being misidentified as a foreign agent and being attacked by the antibodies [13].

Considering the blood supply of the inner ear, the arteries supplying to the inner ear are mainly the anterior 
inferior cerebellar artery and basilar artery, which branch as the anterior vestibular artery and cochlear artery. There may be a blood supply, but the inner ear has no blood collateral. Even though SARS- COV-2 is a virus that has a bigger size so that it does not spread through blood arteries, the big diameters of the virus can result in ischemia thrombosis, thus causing hearing loss. The virus also leads to a high production of proinflammatory cytokines that results in hearing loss [14]. Cases in which the virus results in audio vestibular symptoms apart from upper respiratory tract infection, considering both of these as an emergency, is a major challenge to deal with the upper respiratory tract infections and deal with the reversal of hearing loss [12]. There have been narrative reviews on hearing loss and COVID 19 reported by some authors. Two systematic reviews were conducted recently by Almufarrij \& Munro in 2021 and Almufarrij et al. in 2020 on exploring audiovestibular symptoms in COVID19. The authors have aimed extensively to document the effect of SARS-COV-2 on the audio vestibular system $[14,15]$. However, with sudden sensorineural hearing being an emergency and requiring immediate treatment, there is a need to review case reports related to sudden sensorineural hearing loss and COVID19 as it is required in the need for the hour with a spurge seen in COVID19 cases currently.

\section{Methods}

Research design: This was a systematic review of case reports.

Search strategy: Articles published from various peerreviewed journals were searched in different databases like PubMed, PubMed Central, science direct, J-GATE, Google Scholar, and a manual Google Search. The advanced search using the BOOLEAN operations such as AND, OR, and NOT was used for all databases, and its respective keyword extraction was also incorporated. The key words/ MeSH (Medical Subject Headings) terms were as follows: ((()(( “COVID-19”[MeSH Terms] OR “COVID-19”[All Fields] OR "COVID19"[All Fields]) OR (("coronavirus" [MeSH Terms] OR "coronavirus"[All Fields]) AND ("disease" [MeSH Terms] OR "disease"[All Fields]))) OR ("sars-cov-2" [MeSH Terms] OR "sars-cov2"[All Fields] OR "sars cov 2"[All Fields])) OR ("sarscov-2"[MeSH Terms] OR "sars-cov-2"[All Fields] OR "2019 ncov"[All Fields])) OR ("sars-cov-2"[MeSH Terms] OR "sars-cov-2"[All Fields] OR ("novel"[All Fields] AND "coronavirus"[All Fields]) OR "novel coronavirus"[All Fields])) AND (sudden[All Fields] AND ("hearing loss, sensorineural" [MeSH Terms] OR ("hearing"[All Fields] AND "loss"[All Fields] AND "sensorineural" [All Fields]) OR "sensorineural hearing
loss"[All Fields] OR ("sensorineural"[All Fields] AND "hearing"[All Fields] AND "loss"[All Fields])))) OR ("hearing loss, sudden" [MeSH Terms] OR ("hearing"[All Fields] AND "loss"[All Fields] AND "sudden"[All Fields]) OR "sudden hearing loss"[All Fields] OR ("sudden"[All Fields] AND "hearing"[All Fields] AND "loss"[All Fields]))) OR (sudden[All Fields] AND reduced[All Fields] AND ("hearing"[MeSH Terms] OR "hearing"[All Fields]) AND ("sensitivity and specificity"[MeSH Terms] OR ("sensitivity"[All Fields] AND "specificity"[All Fields]) OR "sensitivity and specificity"[All Fields] OR "sensitivity"[All Fields])) AND ("2020/04/14"[PDat]: “2021/04/13”[PDat]).

\section{Selection of Studies}

\section{Inclusion Criteria}

- Published articles should be from peer-reviewed journals

- The article must be a case report or case series containing human subjects.

- Selection criteria were based on PICOS [16].

P-Population-Individuals with sudden sensorineural hearing loss with a diagnosis of COVID19 on a lab test.

I- Intervention-Intervened using intratympanic/oral steroids.

C-Comparison- No comparison group.

O-Outcome- Better outcomes measured using various subjective and objective tests.

S-Study design-Only case reports/case series were considered.

T-Timings: The cases over a period of one year were included.

\section{Exclusion Criteria}

- Articles that are of a randomized control trial, cohort, cross-sectional, longitudinal, reviews, letter to editors, and short communications were excluded

- Articles with language apart from English were excluded.

- Articles focusing on sudden sensorineural hearing loss due to diseases apart from COVID19 were excluded.

\section{Data Extraction}

The data extraction was carried out by two independent reviewers (UA and PP). Initially, articles from various databases underwent title screening. After filtering out the 
titles, a list of articles underwent abstract screening, and later based on the inclusion and exclusion criteria, the filtered articles underwent a full-text screening. The number of articles were finalized after the quality analysis. The duplicates were identified and removed with the help of the Mendeley reference managing software. The authors followed the PRISMA guidelines from article screening to writing [17].

\section{Quality Analysis (Risk of Bias)}

The quality analysis was carried out by two authors (UA and PP) using the NIH quality assessment tool for case studies. One way to avoid the discrepancy between the two reviewers was to appoint a third reviewer to deal with the disagreements. However, there were no disagreements between the authors, the third review by another author was not performed. The quality assessment tool for case studies was assessed to avoid bias between the two reviewers potentially. It had a total of nine questions that were to be answered with a yes/no/other with an overall rating of good, fair, and poor [18]. Some of the questions were: Was the study question or objective clearly stated? Was the study population clearly and fully described, including a case definition? Were the cases consecutive? Were the subjects comparable?

An additional tool called the Oxford Centre for Evidence-Based Medicine (OCEBM) was used by both the reviewers to grade the studies based on the level of evidence [19].

\section{Results}

A total of 3876 articles were obtained after combining the search results from all the databases, out of which 2000 articles were duplicates. Around 1876, articles underwent title screening, under which abstract screening was done for 24 articles, and 7 articles were finalized based on a fulltext screening [20-26]. The quality analysis was carried out using the NIH quality assessment tool for case studies by two independent reviewers. Both the reviewers concluded that questions 3,4 , and 8 were not applicable for all the articles, and all articles were adjudged of fair quality based on the questions. None of them were rejected based on the quality analysis. Concerning the level of evidence, both the authors concluded that all articles were judged, with level IV evidence being case reports based on the OCEBM scale. Figure 1 illustrates the hierarchy of selection of articles from screening to finalization, and Table 1 depicts the study characteristics and scores of the OCEBM grading.

All the seven of finalized articles reported the incidence of sudden sensorineural hearing loss in patients in COVID-
19 along with other otological symptoms and appropriate use of audiological test battery. All the articles reported Pure Tone Audiometry as a standard audiological test used for evaluating hearing sensitivity in individuals with COVID-19. Only Chern et al. [21], reported the presence of a bilateral moderate sensorineural hearing loss while other authors reported a unilateral hearing loss with the hearing threshold of poorer ear ranging from moderate to severe sensorineural hearing loss and the better ear thresholds ranging from normal hearing to mild sensorineural hearing loss. None of the authors reported the presence of middle ear pathology on otoscopic examination and immittance audiometry. Except Chern et al. [21] and Kilic et al. [23], all authors reported tinnitus in at least one ear, while Chern et al. reported the presence of aural fullness, vertigo, nausea, and vomiting Otological symptoms.

Six articles have reported the possible treatment options for SSNHL due to COVID-19 and appropriate documentation of treatment outcomes except for Chirakkal et al., where they did not report treatment options in their study. The treatment option used steroids either in the form of intratympanic or oral, and outcome measures revealed improvement in threshold post-treatment.

\section{Discussion}

Sudden sensorineural hearing loss is most often defined as a sensorineural hearing loss of $30 \mathrm{~dB}$ or greater over at least three contiguous audiometric frequencies occurring over $72 \mathrm{~h}$. Nearly all cases are unilateral; less than $2 \%$ of patients have bilateral involvement, and typically, bilateral involvement is sequential [27]. Hughes et al. 2020 listed the causes for sudden sensorineural hearing loss, which included infectious causes: meningococcal meningitis, herpes virus (Simplex, zoster, and varicella), mumps, HIV, mononucleosis, mycoplasma, cryptococcal meningitis, toxoplasmosis, syphilis, cytomegalovirus, and rubella. Traumatic causes: perilymphatic fistula, inner ear decompression sickness, temporal bone fracture, inner ear concussion, otologic surgery, surgical complications of nonotologic surgery. Neoplastic causes: Acoustic neuroma, leukemia, myeloma, metastasis to the internal auditory canal, meningeal carcinomatosis, contralateral deafness after acoustic neuroma surgery. Immunological causes: primary immune inner ear disease, temporal arteritis, Wegener's granulomatosis, Cogan's syndrome, polyarteritis, delayed contralateral endolymphatic hydrops. Toxic causes: snake bite, ototoxicity. Circulatory causes: vascular disease/alteration of microcirculation, a vascular disease associated with mitochrondriopathy, vertebrobasilar insufficiency, red blood cell deformity, sickle cell disease, anomalous carotid artery, and cardiopulmonary bypass. 
Fig. 1 Depicts a flowchart that shows the number of articles screened and finalized for review
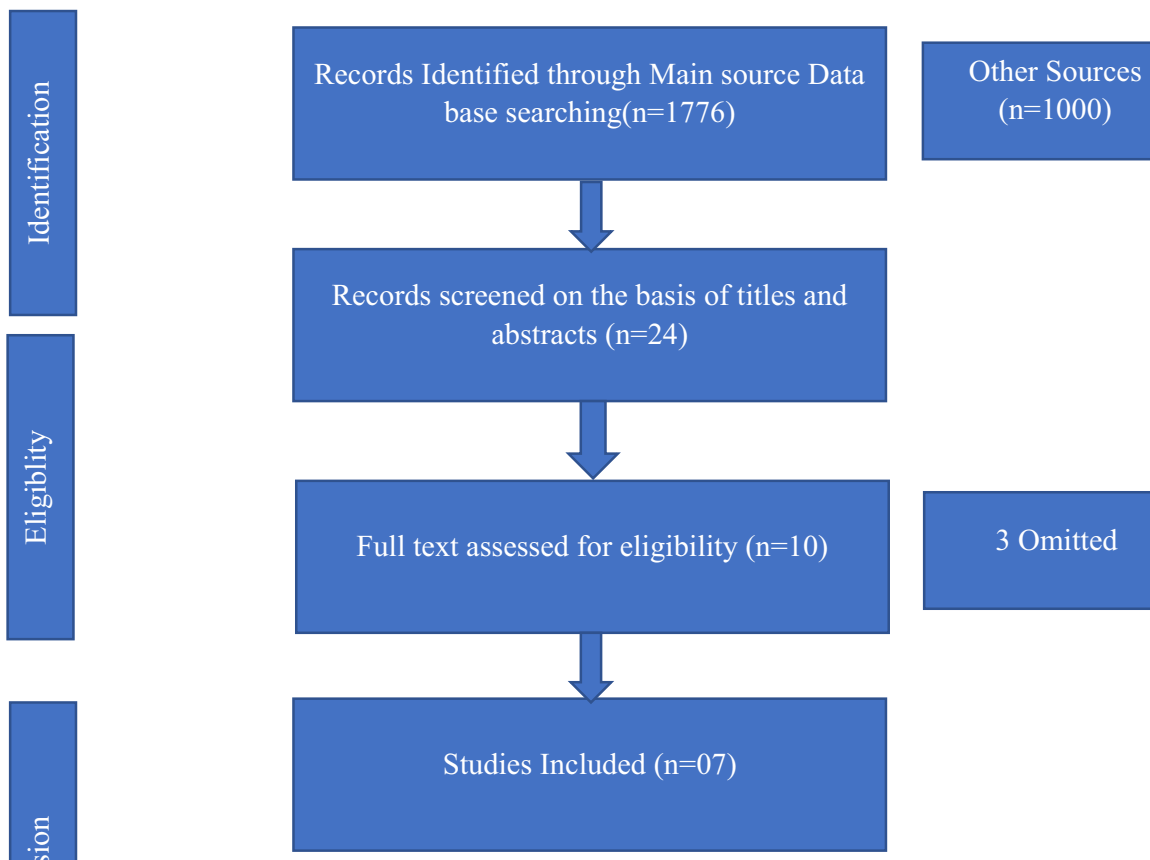

$(n=1000)$

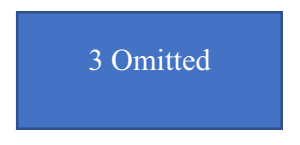

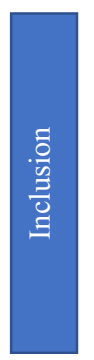

Table 1 Study Characteristics and Quality Analysis

\begin{tabular}{|c|c|c|c|c|c|c|c|}
\hline $\begin{array}{l}\text { Sl } \\
\text { No }\end{array}$ & Author Name & Year & Country & $\begin{array}{l}\text { Type of } \\
\text { study }\end{array}$ & No. of patients & $\begin{array}{l}\text { OCEBM } \\
\text { Grade }\end{array}$ & $\begin{array}{l}\text { Quality } \\
\text { Analysis }\end{array}$ \\
\hline 1 & $\begin{array}{l}\text { Lamounier } \\
\text { et al.[20] }\end{array}$ & 2020 & Brazil & $\begin{array}{l}\text { Case } \\
\text { report }\end{array}$ & 1 & IV & Fair \\
\hline 2 & Chern et al.[21] & 2020 & U.S.A & $\begin{array}{l}\text { Case } \\
\text { report }\end{array}$ & 1 & IV & Fair \\
\hline 3 & Lang et al.[22] & 2020 & Ireland & $\begin{array}{l}\text { Case } \\
\text { report }\end{array}$ & 1 & IV & Fair \\
\hline 4 & Kilic et al .[23] & 2020 & Turkey & $\begin{array}{l}\text { Case } \\
\text { series }\end{array}$ & $\begin{array}{l}5 \text { cases with SSNHL ( } 4 \text { cases with RT-PCR - Negative and } 1 \\
\text { case -Positive) }\end{array}$ & IV & Fair \\
\hline 5 & $\begin{array}{l}\text { Rhman and } \\
\text { Wahid[24] }\end{array}$ & 2020 & Egypt & $\begin{array}{l}\text { Case } \\
\text { report }\end{array}$ & 1 & IV & Fair \\
\hline 6 & $\begin{array}{l}\text { Chirakkal } \\
\text { et al.[25] }\end{array}$ & 2021 & Qatar & $\begin{array}{l}\text { Case } \\
\text { report }\end{array}$ & 1 & IV & Fair \\
\hline 7 & $\begin{array}{l}\text { Koumpa et al } \\
\text {.[26] }\end{array}$ & 2020 & UK & $\begin{array}{l}\text { Case } \\
\quad \text { report }\end{array}$ & 1 & IV & Fair \\
\hline
\end{tabular}

*RT-PCR- Reverse Transcription - Polymerase Chain Reaction, OCEBM - Oxford Centre for Evidence Based Medicine

Neurologic causes: multiple sclerosis and focal pontine ischemia. Most of the time, SSNHL is idiopathic, explained by the theories of membrane break, vascular compression, stress response, and immunologic [28].

The incidence of SSNHL associated with viral infections has been linked to three mechanisms: neuritis caused by the viral infection invading the cochlear nerve, viral involvement of perilymphatic tissues and cochlea leading to cochleitis, and the stress response caused by the crossreaction of the antigens in the inner ear due to viral infection [23].

The current review explains SSNHL caused by COVID19. All seven articles document case reports of individuals who got SSNHL due to COVID-19 and imply a direct 
Table 2 Depicts the summary of all reports reviewed

\begin{tabular}{|c|c|c|c|c|c|c|}
\hline Study & $\begin{array}{l}\text { Otological } \\
\text { symptoms } \\
\text { reported }\end{array}$ & $\begin{array}{l}\text { Audiological } \\
\text { tests }\end{array}$ & Findings & Treatment & $\begin{array}{l}\text { Treatment } \\
\text { Outcomes }\end{array}$ & Implications \\
\hline $\begin{array}{l}\text { Lamounier } \\
\text { et al .[20] }\end{array}$ & $\begin{array}{l}\text { Reduced } \\
\text { hearing } \\
\text { sensitivity in } \\
\text { the right ear, } \\
\text { disabling } \\
\text { tinnitus }\end{array}$ & $\begin{array}{l}\text { Otoscopy. Pure } \\
\text { Tone } \\
\text { Audiometry, } \\
\text { Immittance } \\
\text { Audiometry }\end{array}$ & $\begin{array}{l}\text { Otoscopy - Normal } \\
\text { PTA- Rt: Severe } \\
\text { SNHL Lt: Mild } \\
\text { NHL at } 4 \text { \& } \\
8 \mathrm{kHz} \\
\text { Immittance- } \\
\text { Bilateral A-type } \\
\text { tympanogram } \\
\text { with bilateral } \\
\text { contralateral } \\
\text { stapedial reflexes } \\
\text { absent }\end{array}$ & $\begin{array}{l}\text { Combined } \\
\text { corticosteroid } \\
\text { therapy (oral and } \\
\text { intratympanic for } \\
\text { right ear) }\end{array}$ & $\begin{array}{l}\text { Isolated threshold } \\
\text { improvements at } \\
250 \mathrm{~Hz} \text { (from } 60 \\
\text { to } 15 \mathrm{~dB} \text { ) in right } \\
\text { ear. } 4,6 \text {, and } \\
8 \mathrm{kHz} \text { thresholds } \\
\text { came down to } 15 \text {, } \\
5 \text {, and } 20 \mathrm{~dB} \text { resp. } \\
\text { Tinnitus still } \\
\text { persisted }\end{array}$ & $\begin{array}{l}\text { Among the three } \\
\text { possible } \\
\text { pathophysiological } \\
\text { processes that } \\
\text { could result in } \\
\text { SSNHL, they } \\
\text { conclude that a pre- } \\
\text { existed } \\
\text { nonsymptomatic } \\
\text { autoimmune } \\
\text { disorder with this } \\
\text { severe viral } \\
\text { infection would } \\
\text { have aggravated } \\
\text { the } \\
\text { microcirculation }\end{array}$ \\
\hline $\begin{array}{l}\text { Chern } \\
\text { et al.[21] }\end{array}$ & $\begin{array}{l}\text { Bilateral } \\
\text { sudden loss } \\
\text { of hearing, } \\
\text { intermittent } \\
\text { aural } \\
\text { fullness } \\
\text { associated } \\
\text { with vertigo, } \\
\text { nausea, and } \\
\text { vomiting }\end{array}$ & $\begin{array}{l}\text { Otoscopy, pure } \\
\text { tone } \\
\text { audiometry, } \\
\text { word } \\
\text { recognition } \\
\text { scores (WRS), } \\
\text { tympanometry }\end{array}$ & $\begin{array}{l}\text { Otoscopy - Normal } \\
\text { PTA: Rt: } \\
\text { moderate to } \\
\text { severe SNHL } \\
\text { PTA- } 60 \mathrm{~dB} \text {, } \\
\text { WRS- } 88 \% \text { ) Lt: } \\
\text { moderate to } \\
\text { profound (PTA- } \\
63 \mathrm{~dB} \text {, WRS- } \\
80 \% \text { ) } \\
\text { Tympanometry- } \\
\text { Normal }\end{array}$ & $\begin{array}{l}\text { Two courses of high- } \\
\text { dose oral prednisone } \\
\text { with taper. } \\
\text { Intratympanic } \\
\text { steroid injection for } \\
\text { the left ear }\end{array}$ & $\begin{array}{l}\text { audiometric testing } \\
\text { was carried out } \\
\text { between intervals } \\
\text { of each treatment } \\
\text { approach. (initial } \\
\text { oral steroid, } \\
\text { intratympanic } \\
\text { steroid and second } \\
\text { doze of oral } \\
\text { steroids) Final } \\
\text { treatment resulted } \\
\text { in Rt: severe to } \\
\text { mild to profound } \\
\text { HL (PTA-45 dB, } \\
\text { WRS-96\%) Lt: } \\
\text { Severe to } \\
\text { profound Mixed } \\
\text { HL (PTA- } 92 \mathrm{~dB}, \\
\text { WRS-0) }\end{array}$ & $\begin{array}{l}\text { The otologic } \\
\text { symptoms which } \\
\text { were reported } \\
\text { could be due to the } \\
\text { intra labyrinthine } \\
\text { haemorrhage, } \\
\text { which resulted } \\
\text { from the viral } \\
\text { invasion of the } \\
\text { labyrinth }\end{array}$ \\
\hline $\begin{array}{l}\text { Lang et al. } \\
\text { [22] }\end{array}$ & $\begin{array}{l}\text { Right-sided } \\
\text { reduced } \\
\text { hearing } \\
\text { sensitivity } \\
\text { and tinnitus }\end{array}$ & $\begin{array}{l}\text { Pure tone } \\
\text { audiometry }\end{array}$ & $\begin{array}{l}\text { PTA: Rt: Severe to } \\
\text { Profound hearing } \\
\text { loss at } 2,4 \text { and } \\
8 \mathrm{kHz} . \mathrm{Lt}: \\
\text { Hearing } \\
\text { sensitivity within } \\
\text { normal limits }\end{array}$ & $\begin{array}{l}\text { Oral intake of } \\
\text { corticosteroids }\end{array}$ & $\begin{array}{l}\text { No significant } \\
\text { improvement in } \\
\text { hearing was } \\
\text { reported }\end{array}$ & $\begin{array}{l}\text { The authors } \\
\text { highlighted a } \\
\text { controversial } \\
\text { finding of } \\
\text { ineffectiveness of } \\
\text { usage of } \\
\text { corticosteroids in } \\
\text { treatment of } \\
\text { SSNHL due to } \\
\text { COVID-19 }\end{array}$ \\
\hline $\begin{array}{l}\text { Kilic } \\
\text { et al.[23] } \\
\begin{array}{l}\text { (Case with } \\
\underline{\text { RT- }}+\mathrm{ve})\end{array}\end{array}$ & $\begin{array}{l}\text { Right-sided } \\
\text { sudden } \\
\text { hearing loss }\end{array}$ & $\begin{array}{l}\text { TFT Weber test, } \\
\text { Pure tone } \\
\text { audiometry, } \\
\text { Tympanometry }\end{array}$ & $\begin{array}{l}\text { TFT Weber: } \\
\text { Lateralized to ear } \\
\text { with normal } \\
\text { hearing, PTA: Rt: } \\
\text { Moderately severe } \\
\text { SNHL at low } \\
\text { frequencies, Lt: } \\
\text { Normal hearing } \\
\text { sensitivity }\end{array}$ & $\begin{array}{l}\text { Oral } \\
\text { hydroxychloroquine } \\
200 \mathrm{mg} \text { twice daily } \\
\text { for } 5 \text { days (as per } \\
\text { Covid guidelines of } \\
\text { Republic of } \\
\text { Turkey's Health } \\
\text { Ministry) }\end{array}$ & $\begin{array}{l}\text { Hearing returned to } \\
\text { normal limits post } \\
\text { treatment }\end{array}$ & $\begin{array}{l}\text { They suggest SSNHL } \\
\text { as a nonspecific } \\
\text { symptom } \\
\text { coronavirus } \\
\text { infection and } \\
\text { spreading } \\
\text { awareness } \\
\text { regarding these } \\
\text { nonspecific } \\
\text { symptoms help in } \\
\text { early identification } \\
\text { and treatment and } \\
\text { prevent spreading } \\
\text { of infection }\end{array}$ \\
\hline
\end{tabular}


Table 2 continued

\begin{tabular}{|c|c|c|c|c|c|c|}
\hline Study & $\begin{array}{l}\text { Otological } \\
\text { symptoms } \\
\text { reported }\end{array}$ & Audiological tests & Findings & Treatment & $\begin{array}{l}\text { Treatment } \\
\text { Outcomes }\end{array}$ & Implications \\
\hline $\begin{array}{l}\text { Rhman and } \\
\text { Wahid } \\
{[24]}\end{array}$ & $\begin{array}{l}\text { Left-sided } \\
\text { hearing } \\
\text { loss } \\
\text { preceded } \\
\text { by } \\
\text { worsening } \\
\text { tinnitus }\end{array}$ & $\begin{array}{l}\text { Otoscopy, TFTRinne } \\
\text { and Weber, Pure } \\
\text { Tone Audiometry }\end{array}$ & $\begin{array}{l}\text { Tympanometry: Normal } \\
\text { Otoscopy - Normal } \\
\text { TFT: Bilateral positive } \\
\text { Rinne, Weber- } \\
\text { Lateralized to the right } \\
\text { side, PTA: Rt: Normal } \\
\text { hearing sensitivity, Lt: } \\
\text { Severe SNHL }\end{array}$ & $\begin{array}{l}\text { Intratympanic } \\
\text { corticosteroids } \\
\text { ( } 3 \text { sessions } \\
\text { with } 5 \text { days } \\
\text { intervals) }\end{array}$ & $\begin{array}{l}\text { Improvement } \\
\text { of hearing } \\
\text { levels from } \\
\text { severe } \\
\text { degree to } \\
\text { moderate } \\
\text { SNHL }\end{array}$ & $\begin{array}{l}\text { They reported that } \\
\text { SSNHL due to } \\
\text { coronavirus can be } \\
\text { present in patients who } \\
\text { shows no other classic } \\
\text { symptoms of COVID- } \\
19\end{array}$ \\
\hline $\begin{array}{l}\text { Chirakkal } \\
\text { et al. } \\
\text { [25] }\end{array}$ & $\begin{array}{l}\text { Tinnitus and } \\
\text { reduced } \\
\text { hearing } \\
\text { sensitivity } \\
\text { in left ear }\end{array}$ & $\begin{array}{l}\text { TFT, Immittance } \\
\text { audiometry, pure } \\
\text { tone audiometry, } \\
\text { speech recognition } \\
\text { scores, Otoacoustic } \\
\text { emissions and } \\
\text { tinnitus evaluation }\end{array}$ & $\begin{array}{l}\text { Tympanometry: Normal } \\
\text { TFT Weberlateralised } \\
\text { to left side for } 250 \mathrm{~Hz} \\
\text { and centralized for } \\
\text { other test frequencies. } \\
\text { PTA: Rt: normal } \\
\text { hearing sensitivity, Lt: } \\
\text { rising minimal hearing } \\
\text { loss, }(30.25 \text { and } 15 \mathrm{~dB} \\
\text { at } 250,500 \text { and } 1 \mathrm{k} \\
\text { resp.) Speech } \\
\text { recognition - } 100 \% \text { in } \\
\text { both ears Immittance } \\
\text { revealed - normal } \\
\text { tympanogram and } \\
\text { absent left ipsilateral } \\
\text { stapedial reflexes. } \\
\text { OAE: TEAOE and } \\
\text { DPOAE was pass in } \\
\text { both ears except at low } \\
\text { frequencies in left ear. } \\
\text { Tinnitus was matched } \\
\text { at } 4 \mathrm{kHz}, 10 \mathrm{~dB}\end{array}$ & $\begin{array}{l}\text { Not mentioned } \\
\quad \text { about } \\
\text { treatment }\end{array}$ & & $\begin{array}{l}\text { The authors reported that } \\
\text { coronavirus infection } \\
\text { can have an impairing } \\
\text { effect on outer hair } \\
\text { cells of cochlea which } \\
\text { was explained by mild } \\
\text { SNHL and absence of } \\
\text { OAEs at low } \\
\text { frequencies }\end{array}$ \\
\hline $\begin{array}{l}\text { Koumpa } \\
\text { et al.[26] }\end{array}$ & $\begin{array}{l}\text { Left-sided } \\
\text { tinnitus } \\
\text { and } \\
\text { sudden } \\
\text { onset of } \\
\text { hearing } \\
\text { loss }\end{array}$ & $\begin{array}{l}\text { Otoscopy, } \\
\text { tympanometry, TFT } \\
\text { Rinne and weber, } \\
\text { pure tone } \\
\text { audiometry }\end{array}$ & $\begin{array}{l}\text { Otoscopy - normal, TFT } \\
\text { Rinne: -ve on left side } \\
\text { and weber lateralised to } \\
\text { right side, Immittance } \\
\text { audiometry- normal } \\
\text { PTA: right ear - normal } \\
\text { hearing sensitivity Lt: } \\
65,75,75,85 \mathrm{~dB} \text { at } 2 \text {, } \\
3,4, \text { and } 6 \mathrm{kHz} \text { resp. }\end{array}$ & $\begin{array}{l}\text { Oral steroids for } \\
7 \text { days } \\
\text { followed by } \\
\text { intratympanic } \\
\text { steroids }\end{array}$ & $\begin{array}{l}\text { Improvement in } \\
\text { hearing } \\
\text { thresholds to } \\
55,60,60 \\
\text { and } 80 \mathrm{~dB} \text { at } \\
2,3,4 \text { and } \\
6 \mathrm{kHz} \text { resp. }\end{array}$ & $\begin{array}{l}\text { They reported tinnitus } \\
\text { and sudden hearing loss } \\
\text { can occur as a result of } \\
\text { coronavirus infections } \\
\text { and those patients can } \\
\text { be subjected to } \\
\text { intratympanic steroid } \\
\text { treatments }\end{array}$ \\
\hline
\end{tabular}

*SSNHL- Sudden Sensorineural Hearing Loss, SNHL- Sensorineural Hearing loss, PTA-Pure Tone Average, WRS- Word Recognition Scores, TFT- Tuning Fork Test, OAE- Oto Acoustic Emissions, TEOAE - Transient Evoked Oto Acoustic Emissions, DPOAE- Distortion Product Oto Acoustic Emission

association between COVID-19 and onset of SSNHL [20-26]. Like other viruses resulting in sudden SNHL, Coronavirus can also be expected to take up the same routes and reactions over the labyrinth and cochlear nerve responsible for the otological symptoms. The three possible pathophysiology by which the coronavirus could damage the hearing. First, it could damage the auditory center in the temporal lobe, which happens as a viral infection mediated consequence. Second, it could change the microvascular structure functions of the inner ear, followed by COVID-19 infection, resulting in a thrombus or an embolus that interrupts the blood flow to the inner ear. Third, there could be any multi-organ involvement or can occur as a direct peripheral injury to the sensory cells of the cochlear due to neurotropism of the virus [10, 29, 30].

Coronavirus infection also can damage the outer hair cells of the cochlea.It was concluded from the study by Chirakkal et al. 2021, which showed the absence of TEAOE and DPOAE at the frequencies where there reduced hearing sensitivity [25]. The virus is also likely to cause intra-labyrinthine hemorrhage due to viral involvement of the labyrinth. It could result in symptoms apart 
from hearing loss like tinnitus, vertigo, nausea, and vomiting. An intact blood supply to the cochlea is necessary for maintaining the essential fluid and ionic balance to the inner ear. So, an interruption in cochlear microcirculation can result in endolymphatic fluid balance, ion transport, and endo-cochlear potentials, which are crucial for normal hearing [31].

Even in patients who do not exhibit typical symptoms of COVID-19 infection, there could be SSNHL as a nonspecific symptom [23]. This can be used to spread awareness among the population and used during screening for symptoms of infection which would help in the early identification of asymptomatic cases and prevention of infection.

The use of corticosteroids has been reported to yield better outcomes in treating sudden sensorineural hearing loss [32]. With existing controversies on usage of steroids in COVID-19 cases, intratympanic steroids can be used for treating SSNHL caused secondary to COVID-19. Rhman et al. 2020 reported an improvement in hearing after undergoing 3 sessions of intratympanic steroid treatment within 5 days - course in an asymptomatic patient test COVID positing using RT-PCR test [24]. Studies by Koumpa et al. 2020, and Chern et al. 2020, reported a treatment approach combining the oral and intratympanic intake of steroids resulted in improved hearing threshold and improved word recognition scores [21, 26]. There has also been a Turkish study that reported recovery of normal hearing from COVID-19 induced SSNHL after the administration of Oral hydroxychloroquine, which was followed according to COVID guidelines of the Republic of Turkey's Health Ministry [23]. Contradictory to these findings, there has also been a study reported by Lang et al. which showed no significant improvement after oral steroid treatment [22].

\section{Limitations and Future Directions}

The number of articles selected for review in the current paper is limited due to the availability of research pertaining only to sudden sensorineural hearing loss and COVID-19. As this would be an initial review of SSNHL and COVID-19, there is a need for a similar systematic review in the future, documenting additional case reports. In addition, there is a need for every clinician to publish their findings and treatment outcomes if they get patients with SSNHL post-COVID-19. There is variability in results from individual to individual and more publications would provide adequate knowledge on how to handle cases with SSNHL and COVID-19.

\section{Conclusions}

It has been established from the review that there is a direct association between COVID-19 and SSNHL. The virus can affect the auditory system, either directly infecting the inner ear causing labyrinthitis/neuritis, by forming a thrombus/embolus affecting the microcirculation in the inner ear or affecting the auditory centre in the temporal lobe. Therefore, understanding the aetiology behind COVID-19 causing SSNHL is essential as it provides the clinician the appropriate treatment options for hearing loss caused due to COVID-19, thus minimizing the side effects of the treatment and enhancing the treatment outcomes.

Acknowledgements The authors acknowledge with gratitude Prof. M Pushpavathi, Director, All India Institute of Speech and Hearing, Mysore affiliated to the University of Mysore for permitting to conduct the study at the institute. The authors also like to acknowledge the participants for co-operation.

Author contributions AU, was involved in study design, data collection, analysis of the results and writing the manuscript; PP was involved in study design, stimulus preparation, data collection, analysis of the data, interpretation and writing the manuscript; and PP, was involved in study design, data collection, analysis of the results and writing the manuscript.

Funding There is no funding by any agency for the manuscript.

\section{Declarations}

Conflict of interest The authors report no conflicts of interest. The authors alone are responsible for the content and writing of the paper.

Ethical approval In the present study, all the testing procedures were carried out on humans using non-invasive techniques, adhering to the guidelines of the Ethics Approval Committee of the institute.

Informed Consent All the procedures were explained to the participants, and informed consent was taken from all the participants of the study.

\section{References}

1. Patel S, Saxena B, Mehta P (2021) IRecent updates in the clinical trials of therapeutic monoclonal antibodies targeting cytokine storm for the management of COVID-19. Heliyon 7:e06158

2. Umashankar A, Prabhu P (2020) Effect of Covid-19 on Individuals with Hearing Impairment in India. J Clin Diagn Res. https://doi.org/10.7860/JCDR/2020/45054.13892

3. Graichen $H$ (2021) What is the difference between the first and the second/third wave of Covid-19?-German perspective. J Orthop 24:A1-A3

4. Yadav R, Bansal R, Budakoty S, Barwad P (2020) COVID-19 and sudden cardiac death: a new potential risk. Indian Heart $\mathrm{J}$ 72(5):333

5. Adapa S, Chenna A, Balla M, Merugu GP, Koduri NM, Daggubati SR, Konala VM (2020) COVID-19 pandemic causing acute kidney injury and impact on patients with chronic kidney disease and renal transplantation. J Clin Med Res 12(6):352 
6. Cai Q, Huang D, Yu H, Zhu Z, Xia Z, Su Y, Xu L (2020) COVID-19: abnormal liver function tests. J Hepatol 73(3):566-574

7. Beyrouti R, Adams ME, Benjamin L, Cohen H, Farmer SF, Goh YY, Werring DJ (2020) Characteristics of ischaemic stroke associated with COVID-19. J Neurol Neurosurg Psychiatry 91(8):889-891

8. Smyk W, Janik MK, Portincasa P, Milkiewicz P, Lammert F, Krawczyk M (2020) COVID-19: focus on the lungs but do not forget the gastrointestinal tract. Euro J Clin Investig 50(9):e13276

9. Sriwijitalai W, Wiwanitkit V (2020) Hearing loss and COVID19: a note. Am J Otolaryngol. 41(3):102473

10. Mustafa MWM (2020) Audiological profile of asymptomatic Covid-19 PCR-positive cases. Am J Otolaryngol 41(3):102483

11. Munro KJ, Uus K, Almufarrij I, Chaudhuri N, Yioe V (2020) Persistent self-reported changes in hearing and tinnitus in posthospitalisation COVID-19 cases. Int J Audiol 59(12):889-890

12. Karimi-Galougahi M, Naeini AS, Raad N, Mikaniki N, Ghorbani J (2020) Vertigo and hearing loss during the COVID-19 pandemic-is there an association? Acta Otorhinolaryngol Ital 40(6):463

13. Saniasiaya $\mathbf{J}$ (2021) Hearing loss in SARS-CoV-2: what do we know? Ear, Nose Throat J 100(2_suppl):152S-154S

14. Almufarrij I, Munro KJ (2021) One year on: an updated systematic review of SARS-CoV-2, COVID-19 and audio-vestibular symptoms. Int J Audiol. https://doi.org/10.1080/14992027.2021.1896793

15. Almufarrij I, Uus K, Munro KJ (2020) Does coronavirus affect the audio-vestibular system? A rapid systematic review. Int $\mathbf{J}$ Audiol 59(7):487-491

16. Methley AM, Campbell S, Chew-Graham C, McNally R, Cheraghi-Sohi S (2014) PICO, PICOS and SPIDER: a comparison study of specificity and sensitivity in three search tools for qualitative systematic reviews. BMC Health Serv Res 14(1):1-10

17. Moher D, Liberati A, Tetzlaff J, Altman DG, Prisma Group (2009) Preferred reporting items for systematic reviews and metaanalyses: the PRISMA statement. PLoS Med 6(7):e1000097

18. Conway CM, Karpicke J, Anaya EM, Henning SC, Kronenberger WG, Pisoni DB (2011) Nonverbal cognition in deaf children following cochlear implantation: motor sequencing disturbances mediate language delays. Dev Neuropsychol 36(2):237-254

19. Study Quality Assessment Tools I NHLBI, NIH [Internet]. [cited 2021 April 13]. Available from: https://www.nhlbi.nih.gov/health-topics/study-qualityassessment-tools. Accessed on April 132021
20. Lamounier P, Gonçalves VF, Ramos HVL, Gobbo DA, Teixeira RP, Dos Reis PC, Costa CC (2020) A 67-Year-Old woman with sudden hearing loss associated with SARS-CoV-2 infection. Am J Case Rep 21:e927519-e927521

21. Chern A, Famuyide AO, Moonis G, Lalwani AK (2021) Bilateral Sudden Sensorineural Hearing Loss and Intralabyrinthine Hemorrhage in a Patient With COVID-19. Otol Neurotol 42(1):e10

22. Lang B, Hintze J, Conlon B (2020) Coronavirus disease 2019 and sudden sensorineural hearing loss. J Laryngol Otol 134(11):1026-1028

23. Kilic O, Kalcioglu MT, Cag Y, Tuysuz O, Pektas E, Caskurlu H, Cetın F (2020) Could sudden sensorineural hearing loss be the sole manifestation of COVID-19? An investigation into SARSCOV-2 in the etiology of sudden sensorineural hearing loss. Int $\mathbf{J}$ Infect Dis 97:208-211

24. Rhman SSA, Wahid AAA (2020) COVID-19 and sudden sensorineural hearing loss, a case report. Otolaryngology Case Reports

25. Chirakkal P, Al Hail AN, Zada N, Vijayakumar DS (2021) COVID-19 and Tinnitus. Ear, Nose Throat J 100(2_suppl):160S$162 \mathrm{~S}$

26. Koumpa FS, Forde CT, Manjaly JG (2020) Sudden irreversible hearing loss post COVID-19. BMJ Case Rep CP 13(11):e238419

27. Mattox DE, Simmons FB (1977) Natural history of sudden sensorineural hearing loss. Ann Otol, Rhinol Laryngol 86(4):463-480

28. Hughes GB, Freedman MA, Haberkamp TJ, Guay ME (1996) Sudden sensorineural hearing loss. Otolaryngol Clin North Am 29(3):393-405

29. Cure E, Cure MC (2020) Comment on "Hearing loss and COVID-19: a note." Am J Otolaryngol 41(4):102513

30. Harenberg J, Jonas JB, Trecca EM (2020) A liaison between sudden sensorineural hearing loss and SARS-CoV-2 infection. Thromb Haemost 120(09):1237-1239

31. Shi X (2011) Physiopathology of the cochlear microcirculation. Hear Res 282(1-2):10-24

32. Hara JH, Zhang JA, Gandhi KR, Flaherty A, Barber W, Leung MA, Burgess LP (2018) Oral and intratympanic steroid therapy for idiopathic sudden sensorineural hearing loss. Laryngoscope Investig Otolaryngol 3(2):73-77

Publisher's Note Springer Nature remains neutral with regard to jurisdictional claims in published maps and institutional affiliations. 